\title{
Morphological and Molecular Variation in a Collection of Eggplants from a Secondary Center of Diversity: Implications for Conservation and Breeding
}

\author{
Jaume Prohens, José M. Blanca, and Fernando Nuez ${ }^{1}$ \\ Centro de Conservación y Mejora de la Agrodiversidad Valenciana, Universidad Politécnica de Valencia, \\ Camino de Vera 14, 46022 Valencia, Spain
}

\begin{abstract}
ADDITIONAL INDEX WORDS. Solanum melongena, cultivar groups, AFLP markers, principal coordinates analysis, genetic diversity, crop evolution

ABSTRACT. Eggplant (Solanum melongena L.) was introduced by the Arabs into Spain. Since then, many local cultivars have arisen. These materials are grouped in four cultivar groups: "round," "semi-long," "long," and "listada de Gandía." We studied the morphological and molecular [amplified fragment length polymorphism (AFLP)] diversity of a collection of 28 Spanish traditional cultivars of eggplant. Four eggplant accessions from different origins were used as controls and three scarlet eggplant (Solanum aethiopicum L.) accessions as outgroups. Morphology and AFLP markers showed that S. melongena and S. aethiopicum are separate taxonomic entities, and that, compared to controls, Spanish eggplants are very variable, indicating that the Iberian Peninsula can be regarded as a secondary center of diversity. Morphological differences were found among cultivar groups in traits other than those used for the grouping although, in some cases, accessions from different cultivar groups shared a similar general morphology. Eggplant cultivar groups also showed some genetic differences, which are revealed in the gene diversity statistics $\left(G_{\mathrm{ST}}=0.30\right)$. Nonetheless, no individual AFLP markers specific and universal to one cultivar group could be found. "Round" cultivars were genetically more diverse than the other cultivar groups. A positive correlation $(r=0.68)$ was found between morphological and molecular distances. However, correlations between geographical and either morphological or molecular distances were low. Results suggest that evolution of eggplants in Spain has involved frequent hybridizations and a frequent movement and exchange of seeds. Structure of diversity among regions indicates that most of the diversity can be collected in single selected regions. All these results have important implications in eggplant germplasm conservation and breeding.
\end{abstract}

The "eggplant complex" includes the cultivated and weedy forms of eggplant and wild species closely related to the crop (Pearce and Lester, 1979). Within this complex, the cultivated forms are represented by groups $\mathrm{G}$ and $\mathrm{H}$ (Lester and Hasan, 1991). Group G is widespread in Southeast Asia and corresponds to primitive cultivars, slightly prickly, with small fruits (3-4 $\mathrm{cm}$ in diameter), which are green with white stripes. Group $\mathrm{H}$ comprises advanced cultivars, unarmed or with just a few tiny prickles, and that yield large (usually $>100 \mathrm{~g}$ ) fruits that may be very variable in color.

The cultivated eggplant was brought from Indochina to North Africa and to the Iberian Peninsula by the Arabs before the 10th century (Prohens and Nuez, 2001; Watson, 1998). From there, although much later and perhaps not before the 14th century, it spread to other European countries like Italy and France (Daunay, 1996). From Spain it was also introduced into America soon after its discovery in 1492 (Nuez et al., 2002). Descriptions and depictions of eggplants found in al-Andalus (Muslim Spain) and other European Middle Age sources match the characteristics of group $\mathrm{H}$, suggesting that eggplants introduced by Arabs into Europe belonged to this group (Nuez et al., 2002; Prohens and Nuez, 2001; Watson, 1998).

Received for publication 5 May 2004. Accepted for publication 9 Aug. 2004. We thank Richard N. Lester and Juan J. Ruiz for their reviews and comments on the original manuscript and EU (RESGEN PL98-113) and Ministerio de Ciencia y Tecnología (RF02-029 and AGL2003-03949) for funding this research.

'To whom reprint requests should be addressed; e-mail address: fnuez@btc. upv.es
Because of the intense commercial trade between al-Andalus and the rest of North Africa and the Middle East, very likely many new eggplant populations were introduced into Spain until the 15th century, when Muslim domination in Spain arrived at an end. These populations were subjected to natural and artificial selection, mutation, genetic drift, and migration, which together with recombination and segregation resulting from occasional hybridization (Kalloo, 1993; Sandambam, 1964) probably led to an increase of variation. The result was the development of local cultivars with adaptation to specific environmental conditions and suited to different uses (Prohens and Nuez, 2001). In this way in the 12th century, on the basis of fruit and flower color, al-Andalus agronomist Abú-Zacaria (1802) described four cultivars of eggplant in Spain, while at the end of 19th century, and as a consequence of the evolution of local materials and new introductions, Navarro (1880) reported on the existence of more than 30 Spanish traditional cultivars that differed in shape, size, and color, each of which might have had several local variants.

Spanish eggplants are classified in four exclusive groups of cultivars ("round," "semi-long," "long," and "listada de Gandía"), basically distinguished by fruit shape and coloration (Nuez et al., 2002; Prohens et al., 2003). The first three types are distinguished by the length: breadth ratio of the fruit ( $\sim 1$ for "round"; $>1.2$ and $<2$ for "semi-long"; and $>2$ for "long") and are characterized by presenting either uniform fruit color or a secondary color distributed in broad strips. The "listada de Gandía" type is typical of the Spanish Mediterranean region, and is characterized by a white or yellowish background color covered by narrow purple stripes.

Despite the substantial morphological variation of the cultivated 
eggplant, this crop has suffered several genetic bottlenecks during its evolution, which probably restricted its genetic diversity (Spillane and Gepts, 2001). As in the tomato (Lycopersicon esculentum Mill.) (Jenkins, 1948), eggplant was not domesticated in the region where its putative wild ancestors are distributed (Africa and Near East), but in Indochina (Lester and Hasan, 1991). Therefore, domestication probably led to an important founder effect, which was accompanied by isolation from wild relatives, preventing introgression from these materials into the domesticate. Introduction into Europe probably represented an additional bottleneck in the genetic diversity (Prohens and Nuez, 2001).

Studies of the molecular diversity of the "eggplant complex" with seed proteins (Karihaloo et al., 2002; Lester and Hasan, 1991; Pearce and Lester, 1979), isozymes (Lester and Hasan, 1991), allozymes (Isshiki et al., 1994; Karihaloo and Gottlieb, 1995), mitochondrial DNA(Isshiki et al., 2003), chloroplast DNA (Isshiki et al., 1998; Sakata and Lester, 1994, 1997; Sakata et al., 1991), random amplified polymorphic DNA (RAPD) markers (Karihaloo et al., 1995; Nunome et al., 2001), amplified fragment length polymorphism (AFLP) markers (Furini and Wunder, 2004; Mace et al., 1999), and microsatellites (Nunome et al., 2001, 2003) show that cultivated eggplant has a narrow molecular diversity. However, these works have been aimed mainly at examining the relationships among the crop and related wild species and weedy forms, and the number of accessions of group $\mathrm{H}$ (especially of those from the Mediterranean region) studied has been very limited. In addition, the simultaneous evaluation of the morphological and molecular diversity of group $\mathrm{H}$ eggplants would be of great interest in eggplant breeding and conservation of germplasm, as it would give information on the variation and genetic base of the crop, evolution and differentiation among groups of cultivars and regions, and the association between molecular and morphological variation.

AFLP markers have been successfully used to examine the relationships of eggplant with related species (Furini and Wunder, 2004; Mace et al., 1999) and in the development of a genetic map of eggplant (Nunome et al., 2001). In addition, AFLP markers allow a large number of loci to be scored in a single reaction, and have a much better repeatability among laboratories than RAPDs (Jones et al., 1997). It is because of these reasons that we consider that AFLP markers may be a useful tool to study the diversity of group $\mathrm{H}$ eggplants.

In this work we study the morphological and molecular (AFLP) diversity of a collection of Solanum melongena group $\mathrm{H}$. Implications of the results in the conservation of germplasm and in eggplant breeding are discussed.

\section{Material and Methods}

Plant material. Thirty-two accessions corresponding to $S$. melongena group $\mathrm{H}$ were used for the present study. Twenty-eight S. melongena accessions corresponded to local Spanish cultivars of the "round," "semi-long," "long," or "listada de Gandía" groups from the main producing regions (Table 1). Four accessions, one from China ("round"), one from Cuba ("semi-long"), one from France ("long"), and a Spanish commercial selection of "listada de Gandía" (semillas Clemente, Vitoria, Spain) were used as $S$. melongena controls. Three accessions of the scarlet eggplant (Solanum aethiopicum L. Gilo group) were used as outgroups. All the plant material is part of the collection of the Centro de Conservación y Mejora de la Agrodiversidad Valenciana (Valencia, Spain).
MORPHOLOGICAL CHARACTERIZATION. Five plants per accession were grown in the open air in Valencia (Spain) and were characterized using the primary characterization descriptors developed by the European Eggplant Genetic Resources Network (EGGNET). These descriptors include seven vegetative traits and 28 inflorescence and fruit traits. The states of the descriptors, a complete description on how each trait is measured as well as explicative figures, can be obtained from the authors or consulted in the International Board for Plant Genetic Resources (IBPGR) (1990) and Nuez et al. (2002). Some traits are metric: plant height (cm; P-Height), flowering time (days from sowing; Fl-Time), fruit pedicel length (cm; F-Pedicel), fruit length (cm; F-Length), fruit breadth $(\mathrm{cm}$; F-Breadth), and fruit weight (g; F-Weight); others are measured in an arbitrary scale and are treated as metric (see Table 2 for a list of traits); others are meristic: leaves to first flower (L-First), flowers per inflorescence (Fl-Inflorescence), and fruits per plant (F-Plant); finally, several fruit color traits are qualitative: fruit predominant color (at commercial ripeness), fruit additional color (at commercial ripeness), fruit additional color distribution (at commercial ripeness), and fruit color at physiological ripeness. Each plant was treated as a replication and one measurement was made for whole plant traits (like plant height) and five for the rest of vegetative, inflorescence, and fruit traits. When possible, all measurements of a given trait were made on the same date to avoid differences in the environment or developmental stage of the plants. Traits corresponding to fruit shape and color were used to assign the accessions to cultivar groups.

DNA EXTRACTION AND AFLP ANALYSIS. For each accession, genomic DNA was isolated from young leaves using the DNeasy Plant Mini Kit (Qiagen Inc., Valencia, Calif.) following the protocol of the manufacturer. DNA concentration was quantified on agarose, and a $0.25-\mu \mathrm{g}$ DNA sample was digested by the enzyme combination $\mathrm{EcoRI}$ and $\mathrm{Mse} \mathrm{I}$ at $37^{\circ} \mathrm{C}$ for $2 \mathrm{~h}$. Ligation was performed with the AFLP Core Reagent Kit (Invitrogen Corp., Carlsbad, Calif.) following the instructions of the manufacturer. After ligation, the reaction mixture was diluted 1:10 in TE buffer.

For the preselective amplification, a $5-\mu \mathrm{L}$ aliquot from the DNA dilution was added to a $25-\mu \mathrm{L}$ solution containing $2.5 \mu \mathrm{L}$ of 10x buffer, $0.5 \mu \mathrm{L}$ of primer EcoA $(10 \mathrm{mM}), 0.5 \mu \mathrm{L}$ of primer MseC $(10 \mu \mathrm{M}), 1.0 \mu \mathrm{L}$ of dNTPs $(10 \mathrm{~mm})$, and 0.8 units of Taq polymerase (Roche, Basel, Switzerland). After preamplification, DNA was diluted again 1:10 in TE buffer. The selective amplification was performed on $2-\mu \mathrm{L}$ aliquots using four combinations of primers (Table 3 ). The resulting DNA fragments were separated in a capillary ABI Prism 310 genetic analyser (Applied Biosystems, Foster City, Calif.). Resulting fragments were visualized using Genographer 1.6 software (Benham, 2001) and scored as binary traits $(1=$ present; $0=$ absent $)$. Only those bands falling within the range of 80 to 380 base pairs (bp) were considered.

DATA ANALYSIS. Standardized quantitative and meristic morphological data were used to calculate pairwise Euclidean distances among the accessions using Phyltools software (Buntjer, 2001). For the AFLP data, pairwise genetic similarities were estimated with the Dice (Sorensen) similarity coefficient $S_{i j}=2 a /(2 a+b$ $+c$ ), where $a$ is the number of bands shared by $i$ and $j, b$ is the number of bands present in $i$ and absent in $j$, and $c$ is the number of bands present in $j$ and absent in $i$. The resulting morphological and genetic similarity matrices were used to generate UPGMA (unweighted pair group method using arithmetic means) phenograms using the Phylip software package (Felsenstein, 1993). As recommended by Mohammadi and Prassana (2003), principal components analysis (PCA) was performed for morphological 
Table 1. Source of seed, geographical coordinates, and cultivar group of the materials used for the study of morphological and molecular (AFLP) variation in a collection of Spanish eggplants.

\begin{tabular}{|c|c|c|c|c|c|c|c|}
\hline Accessions & Locality & Province & Region/country & Longitude & Latitude & Altitude (m) & Cultivar group \\
\hline \multicolumn{8}{|c|}{ Solanum melongena Spanish traditional types } \\
\hline ANS3 & Castro del Río & Córdoba & Andalusia & $4^{\circ} 30^{`} \mathrm{~W}$ & $37^{\circ} 45^{\prime} \mathrm{N}$ & 30 & Semi-long \\
\hline ANS6 & Uguíjar & Granada & Andalusia & $2^{\circ} 42^{\prime} \mathrm{W}$ & $36^{\circ} 55^{\prime} \mathrm{N}$ & 120 & Round \\
\hline ANS24 & Carena & Jaén & Andalusia & $3^{\circ} 30^{\prime} \mathrm{W}$ & $38^{\circ} 05^{\prime} \mathrm{N}$ & n.a. ${ }^{\mathrm{z}}$ & Semi-long \\
\hline ANS26 & Santa Fe & Granada & Andalusia & $2^{\circ} 42^{\prime} \mathrm{W}$ & $37^{\circ} 11^{\prime} \mathrm{N}$ & 20 & Semi-long \\
\hline ANS37 & Uguíjar & Granada & Andalusia & $2^{\circ} 42^{\prime} \mathrm{W}$ & $36^{\circ} 55^{\prime} \mathrm{N}$ & 120 & Long \\
\hline BS3 & Porreres & Baleares & Baleares & $2^{\circ} 40^{\prime} \mathrm{E}$ & $39^{\circ} 35^{\prime} \mathrm{N}$ & 150 & Long \\
\hline CS5 & Bítem & Tarragona & Catalonia & $0^{\circ} 30^{\prime} \mathrm{E}$ & $40^{\circ} 50^{\prime} \mathrm{N}$ & 40 & Long \\
\hline CS16 & Vilafranca del Penedés & Barcelona & Catalonia & $1^{\circ} 41^{\prime} \mathrm{E}$ & $41^{\circ} 22^{\prime} \mathrm{N}$ & 30 & Long \\
\hline $\mathrm{CS} 21$ & El Vendrell & Tarragona & Catalonia & $1^{\circ} 32^{\prime} \mathrm{E}$ & $41^{\circ} 13^{\prime} \mathrm{N}$ & 22 & Long \\
\hline CMS2 & Belvis de la Jara & Toledo & Castilla-La Mancha & $4^{\circ} 57^{\prime} \mathrm{W}$ & $39^{\circ} 45^{\prime} \mathrm{N}$ & 505 & Long \\
\hline IVIA25 & n.a. & Valencia & Valencia & n.a. & n.a. & n.a. & Listada de Gandía \\
\hline IVIA 178 & n.a. & Valencia & Valencia & n.a. & n.a. & n.a. & Listada de Gandía \\
\hline IVIA371 & n.a. & Valencia & Valencia & n.a. & n.a. & n.a. & Listada de Gandía \\
\hline IVIA400 & n.a. & Valencia & Valencia & n.a. & n.a. & n.a. & Listada de Gandía \\
\hline IVIA604 & n.a. & Valencia & Valencia & n.a. & n.a. & n.a. & Listada de Gandía \\
\hline MUS3 & Monteagudo & Murcia & Murcia & $1^{\circ} 08^{\prime} \mathrm{W}$ & $38^{\circ} 01^{\prime} \mathrm{N}$ & 40 & Listada de Gandía \\
\hline MUS4 & Orilla del Azarbe & Murcia & Murcia & $1^{\circ} 05^{\prime} \mathrm{W}$ & $38^{\circ} 03^{\prime} \mathrm{N}$ & 30 & Long \\
\hline MUS5 & Zeneta & Murcia & Murcia & $1^{\circ} 00^{\prime} \mathrm{W}$ & $38^{\circ} 01^{\prime} \mathrm{N}$ & 30 & Semi-long \\
\hline MUS6 & Patiño & Murcia & Murcia & $1^{\circ} 09^{\prime} \mathrm{W}$ & $37^{\circ} 58^{\prime} \mathrm{N}$ & 43 & Round \\
\hline MUS7 & Beniaján & Murcia & Murcia & $1^{\circ} 06^{\prime} \mathrm{W}$ & $37^{\circ} 59^{\prime} \mathrm{N}$ & 50 & Long \\
\hline MUS8 & Media Legua & Murcia & Murcia & $1^{\circ} 11^{\prime} \mathrm{W}$ & $37^{\circ} 58^{\prime} \mathrm{N}$ & 60 & Round \\
\hline MUS11 & Totana & Murcia & Murcia & $1^{\circ} 23^{\prime} \mathrm{W}$ & $37^{\circ} 43^{\prime} \mathrm{N}$ & 250 & Round \\
\hline VS2 & Gandía & Valencia & Valencia & $0^{\circ} 11^{\prime} \mathrm{W}$ & $38^{\circ} 59^{\prime} \mathrm{N}$ & 22 & Listada de Gandía \\
\hline VS8 & Valencia & Valencia & Valencia & $0^{\circ} 19^{\prime} \mathrm{W}$ & $39^{\circ} 25^{\prime} \mathrm{N}$ & 15 & Listada de Gandía \\
\hline VS9 & La Aparecida & Alicante & Valencia & $1^{\circ} 00^{\prime} \mathrm{W}$ & $38^{\circ} 04^{\prime} \mathrm{N}$ & 23 & Round \\
\hline VS10 & La Aparecida & Alicante & Valencia & $1^{\circ} 00^{\prime} \mathrm{W}$ & $38^{\circ} 04^{\prime} \mathrm{N}$ & 23 & Semi-long \\
\hline VS19 & Mutxamel & Alicante & Valencia & $0^{\circ} 44^{\prime} \mathrm{W}$ & $38^{\circ} 23^{\prime} \mathrm{N}$ & 63 & Long \\
\hline VS21 & Gandía & Valencia & Valencia & $0^{\circ} 12^{\prime} \mathrm{W}$ & $38^{\circ} 59^{\prime} \mathrm{N}$ & 22 & Long \\
\hline \multicolumn{8}{|c|}{ Solanum melongena controls } \\
\hline ASIS1 & Beijing & Beijing & China & $99^{\circ} 03^{\prime} \mathrm{E}$ & $47^{\circ} 08^{\prime} \mathrm{N}$ & 45 & Round \\
\hline LF324 & & \multicolumn{4}{|c|}{ Breeding line developed by INRA (France) } & & Long \\
\hline \multicolumn{2}{|c|}{ 'Listada de Gandía' } & \multicolumn{4}{|c|}{ Commercial cultivar (Semillas Clemente, Spain) } & & Listada de Gandía \\
\hline SUDS5 & La Habana & La Habana & Cuba & $82^{\circ} 21^{\prime} \mathrm{W}$ & $23^{\circ} 08^{\prime} \mathrm{N}$ & 10 & Semi-long \\
\hline \multicolumn{8}{|c|}{ Solanum aethiopicum } \\
\hline AFRS5 & Luanda & n.a. & Angola & $13^{\circ} 13^{\prime} \mathrm{E}$ & $8^{\circ} 48^{\prime} \mathrm{S}$ & 74 & Gilo \\
\hline IVIA26 & n.a. & n.a. & n.a. & n.a. & n.a. & n.a. & Gilo \\
\hline IVIA94 & n.a. & n.a. & n.a. & n.a. & n.a. & n.a. & Gilo \\
\hline
\end{tabular}

${ }^{\text {nn.a. }}=$ not available.

data, and principal coordinates analysis (PCoA) for AFLP data. Calculations were performed using the NTSYSpc2.0 software package (Applied Biostatistics Inc., Setauket, N.Y.). Correlations between morphological, molecular, and geographical distance matrices were investigated with a Mantel (1967) test.

Genetic diversity was estimated with Popgene software (Yeh and Boyle, 1997). The proportion of polymorphic fragments $(P)$ and total diversity $\left(H_{T}\right)$ was calculated, and total diversity was partitioned into diversity among $\left(D_{S T}\right)$ and within $\left(H_{S}\right)$ groups (Nei, 1973). The relative magnitude of gene differentiation among groups $\left(G_{S T}\right)$ was calculated as the ratio $D_{S T}: H_{S}$.

\section{Results}

MorPhological Characterization. Spanish traditional cultivars of eggplant studied present the typical characteristics of the group H of the "eggplant complex" (Lester and Hasan, 1991): plants vigorous, with relatively few prickles, and with large fruits (>100 g), but exhibit considerable variation for many other morphological traits, in particular for those related to the fruit (Table 4). Despite the diversity of origins of the $S$. melongena controls used, the variation for most traits studied in these materials is comprised within the range observed for Spanish eggplant landraces (Table 4). Solanum aethiopicum accessions studied belong to the Gilo cultivar group, as they have hairy leaves and are not prickly (Lester et al., 1986). S. aethiopicum can be distinguished from $S$. melongena by many morphological features (Table 4).

On the basis of fruit shape and color, six S. melongena accessions corresponded to the "round" group, six to the "semi-long," 11 to the "long," and nine to the "listada de Gandía" (Table 1). "Round" and "semi-long" groups presented a greater variation in the main color (white, green, and a spectrum of colors from lilac gray to black) as well as in the distribution of the color (uniform or with secondary coloration). No "long" cultivars with second- 
Table 2. Morphological quantitative traits measured in an arbitrary scale, codes for the traits, range of values, and description of the scale used for the study of the morphological variation in a collection of Spanish eggplants.

\begin{tabular}{lll}
\hline Trait & Codes & \multicolumn{1}{c}{ Range [scale $]$} \\
\hline Plant growth habit & P-Habit & $1-9[3=$ upright, $7=$ prostrate $]$ \\
Shoot tip anthocyanins intensity & S-Anthocyans & $0-9[0=$ absent, $9=$ very strong $]$ \\
Leaf blade lobing & L-Lobing & $1-9[1=$ very weak, $9=$ very strong $]$ \\
Leaf prickles (upper surface) & L-Prickles & $0-9[0=$ none, $9=$ very many $(>20)]$ \\
Leaf hairs (lower surface) & L-Hairs & $1-9[1=$ very few, $9=$ very many $]$ \\
Leaf surface shape & L-Surface & $1-9[1=$ flat, $9=$ very convex $]$ \\
Corolla color & C-Color & $1-9[1=$ greenish white, $9=$ bluish violet $]$ \\
Fruit shape & F-Shape & $1-9[1=$ broader than long, $9=$ several times broader than long $]$ \\
Fruit curvature & F-Curvature & $1-9[1=$ None, $9=$ U shaped $]$ \\
Fruit cross-section & F-Section & $1-9[1=$ circular, $9=$ very irregular $]$ \\
Fruit widest part & F-Widest & $1-9[3=$ about $1 / 4$ way from base to tip, $7=$ about $3 / 4$ way from base to tip $]$ \\
Fruit apex shape & F-Apex & $1-9[3=$ protruded, $7=$ depressed $]$ \\
Fruit predominant color intensity & F-Color & $1-9[1=$ very light, $9=$ very dark $]$ \\
Fruit flesh color & F-Flesh & $1-9[3=$ white, $7=$ green $]$ \\
Fruit epidermis shininess & F-Shininess & $1-9[3=$ dull, $7=$ shiny $]$ \\
Fruit epidermis surface & F-Surface & $1-9[3=$ smooth, $7=$ rough $]$ \\
Fruit color intensity under calyx & FC-Intensity & $0-9[0=$ none, $9=$ very strong $]$ \\
Fruit calyx color (amount of anthocyanins) & FC-Color & $0-9[0=$ none, $9=$ very strong $]$ \\
Fruit firmness in broadest part & F-Firmness & $1-9[1=$ very soft, $9=$ very hard $]$ \\
Fruit calyx length (relative to the fruit length) & FC-Length & $1-9[1=$ very short $(<10 \%), 9=$ very long $(>75 \%)]$ \\
Fruit calyx prickles & FC-Prickles & $0-9[0=$ none, $9=$ very many $(>30)]$ \\
\hline
\end{tabular}

Table 3. Restriction enzyme, sequence and fluorescent label for the oligonucleotide pre-selective (E-A and M-C) and selective (E-ACG, E-ACT, M-CAA, and MCTA) primers used for the AFLP analysis.

\begin{tabular}{|c|c|c|c|}
\hline Primers & $\begin{array}{c}\text { Restriction } \\
\text { enzyme }\end{array}$ & Sequence & Label \\
\hline E-A & Eco RI & 5'AGACTGCGTACCAATTCA-3' & --- \\
\hline $\mathrm{M}-\mathrm{C}$ & Mse I & 5'-GATGAGTCCTGAGTAAC-3' & --- \\
\hline E-ACG & Eco RI & 5'-AGACTGCGTACCAATTCACG-3' & HEX or NED \\
\hline E-ACT & Eco RI & 5'-AGACTGCGTACCAATTCAAC-3' & FAM \\
\hline M-CAA & Mse I & 5'-GATGAGTCCTGAGTAACAA-3' & --- \\
\hline M-CTA & Mse I & 5'-GATGAGTCCTGAGTAACTA-3' & --- \\
\hline
\end{tabular}

ary color were found, and their color ranged from lilac gray to black. All "listada de Gandía" accessions were lilac gray or purple covered with yellowish or white narrow strips.

Differences among groups of cultivars were not limited to fruit color and shape, as there were differences among them in other vegetative, inflorescence, and fruit traits (Table 5). In this way, "listada de Gandía" cultivars have lower anthocyanin intensity in the shoot tips and a greater leaf blade lobing than the other cultivars. Regarding fruit traits, "round" cultivars are more irregular in fruit cross-section, have a lower fruit color intensity under calyx, and a more intense fruit calyx color than the rest of the cultivars, while the "long" are the most curved and have the firmest fruits, and the "listada de Gandía" have fewer fruits per plant, but of greater weight, and have more prickles on the calyx than the other cultivar groups (Table 5).

Differences among cultivars from the regions with a greater number of accessions (Valencia, Murcia,Andalusia, and Catalonia) were nonsignificant for most of the traits studied, with the exception of some fruit traits (fruit length, breadth, weight, and curvature; data not shown). However, these differences are a consequence of an uneven distribution among regions of the groups of cultivars; when the differences among regions are studied cultivar groupby-cultivar group, no differences are found.
Phenograms performed with morphological data (not shown) show that S. melongena and S. aethiopicum group separately in two consistent clusters. However, when the relationships among the $S$. melongena accessions are studied, the correlation coefficient between the cophenetic and the genetic distances matrices is 0.79 , a value considered to be relatively low (Rohlf, 1992). This low value indicates that some distortion might have occurred, and that the analysis of the relationships among accessions through this method may produce misleading conclusions (Mohammadi and Prasanna, 2003). Therefore, we studied the relationships among $S$. melongena accessions through a PCA. In this analysis, the first and second components (Fig. 1) account for $23.0 \%$ and $15.0 \%$, respectively. The most important traits separating accessions in the first component are fruit shape traits (fruit curvature, length, and breadth), while in the second are traits related to coloration (fruit calyx intensity, stem anthocyanins, calyx color, and fruit calyx color). In general, the projections of the accessions on the fruit traits plot agree with the data on the differences among groups of cultivars (Table 5). However, there are some accessions that are closer to accessions of other cultivar groups than to those of their own group (Fig. 1). Data corresponding to pairwise distances based on morphological data confirm these results. One example is given by accessions ANS3, MUS4, and MUS3, which, despite belonging to different cultivar groups ("semi-long," "long," and "listada de Gandía," respectively) based on fruit shapes, are otherwise morphologically very similar.

Molecular Characterization. A total of 339 fragments ranging from 80 to $380 \mathrm{bp}$ were scored, of which $269(79.4 \%)$ were polymorphic. However, this high degree of polymorphism is mostly due to differences between $S$. melongena and $S$. aethiopicum (Fig. 2). There are 145 fragments specific of S. melongena (92 present in all accessions) and 112 fragments specific of $S$. aethiopicum. Apart from the 70 monomorphic fragments, these species only share 12 polymorphic markers. 
Table 4. Range and mean for the traits measured in the Spanish traditional cultivars and controls of S. melongena and in S. aethiopicum.

\begin{tabular}{|c|c|c|c|c|c|c|}
\hline \multirow[b]{2}{*}{ Trait } & \multicolumn{2}{|c|}{ Spanish traditional S. melongena } & \multicolumn{2}{|c|}{ S. melongena controls } & \multicolumn{2}{|c|}{ S. aethiopicum } \\
\hline & Range & Mean & Range & Mean & Range & Mean \\
\hline No. of accessions & \multicolumn{2}{|c|}{28} & \multicolumn{2}{|c|}{4} & \multicolumn{2}{|c|}{3} \\
\hline Plant growth habit & $1-5^{z}$ & $2.93 y$ & $3-3$ & 3.00 & $5-5$ & 5.00 \\
\hline Plant height $(\mathrm{cm})$ & $50-85$ & 67.92 & $44.6-73.8$ & 57.3 & $76.8-110.6$ & 91.2 \\
\hline Shoot tip anthocyanins intensity & $1-9$ & 4.96 & $1-9$ & 4.50 & $0-0$ & 0.00 \\
\hline Leaf blade lobbing & $1-7$ & 4.43 & $3-7$ & 5.50 & $9-9$ & 9.00 \\
\hline Leaf prickles & $0-3$ & 0.54 & $0-3$ & 0.75 & $0-0$ & 0.00 \\
\hline Leaf hairs & $3-9$ & 6.36 & $5-7$ & 6.50 & $5-5$ & 5.00 \\
\hline Leaf surface shape & $1-5$ & 2.00 & $1-1$ & 1.00 & $5-5$ & 5.00 \\
\hline Flowering time $(\mathrm{d})$ & $53-62$ & 59.25 & $61-62$ & 61.75 & $56-56$ & 56.00 \\
\hline No. of leaves to first flower & $6-10$ & 7.79 & $7-8$ & 7.75 & $8-10$ & 9.00 \\
\hline No. of flowers per inflorescence & $1-3$ & 1.25 & $1-2$ & 1.50 & $2-3$ & 2.67 \\
\hline Corolla color & $5-9$ & 7.07 & $3-7$ & 6.00 & $3-3$ & 3.00 \\
\hline Fruit pedicel length & $4.4-15.2$ & 7.58 & $3.7-9.5$ & 6.63 & $3.4-4.6$ & 4.20 \\
\hline Fruit length $(\mathrm{cm})$ & $9.3-25.8$ & 18.36 & $8.0-21.6$ & 17.13 & $4.7-7.2$ & 6.23 \\
\hline Fruit breadth $(\mathrm{cm})$ & $4.5-12.0$ & 8.37 & $4.9-10.8$ & 8.00 & $3.7-4.3$ & 3.93 \\
\hline Fruit shape & $1-9$ & 6.50 & $1-9$ & 6.00 & $3-7$ & 5.00 \\
\hline Fruit weight & $143-611$ & 322.68 & $191-413$ & 284.00 & $46-97$ & 74.30 \\
\hline Fruit curvature & $1-5$ & 1.86 & $1-3$ & 1.50 & $1-1$ & 1.00 \\
\hline Fruit cross-section & $1-7$ & 2.43 & $1-3$ & 1.50 & $1-1$ & 1.00 \\
\hline Fruit widest part & $5-7$ & 6.50 & $5-7$ & 6.00 & $5-5$ & 5.00 \\
\hline Fruit apex shape & $3-7$ & 6.29 & $5-7$ & 6.00 & $3-7$ & 4.33 \\
\hline Fruit predominant color intensity & $3-9$ & 5.93 & $3-9$ & 6.50 & $5-7$ & 6.33 \\
\hline Fruit flesh color & $1-7$ & 3.36 & $3-7$ & 4.50 & $5-5$ & 5.00 \\
\hline Fruit epidermis shininess & $3-7$ & 5.79 & $5-7$ & 6.50 & $7-7$ & 7.00 \\
\hline Fruit epidermis surface & $3-5$ & 3.36 & $3-5$ & 3.50 & $3-3$ & 3.00 \\
\hline Fruit color intensity under calyx & $0-9$ & 4.50 & $0-7$ & 4.25 & $9-9$ & 9.00 \\
\hline Fruit calyx color & $0-9$ & 1.64 & $0-9$ & 2.50 & $0-0$ & 0.00 \\
\hline Fruit firmness in broadest part & $3-9$ & 5.14 & $3-9$ & 6.50 & $5-9$ & 7.00 \\
\hline Fruit calyx length & $1-3$ & 2.07 & $1-3$ & 2.50 & $1-1$ & 1.00 \\
\hline Fruit calyx prickles & $0-5$ & 2.00 & $1-7$ & 3.00 & $0-0$ & 0.00 \\
\hline Fruits per inflorescence & $1-1$ & 1.00 & $1-1$ & 1.00 & $2-2$ & 2.00 \\
\hline Fruits per plant & $2-11$ & 4.96 & $2-7$ & 4.75 & $10-30$ & 17.00 \\
\hline
\end{tabular}

${ }^{2}$ Range expresses the minimum and maximum modal value for each of the accessions studied.

yMeans were calculated as the average of mean values of all accessions included in each group.

xRange and mean values based on five plants per accessions and one measurement per plant for whole plant traits and five measurements per plant for the rest of vegetative, inflorescence, and fruit traits.

Table 5. Means for each S. melongena cultivar group for which differences in quantitative traits have been detected.

\begin{tabular}{|c|c|c|c|c|}
\hline Trait & Round & Semi-long & Long & Listada de Gandía \\
\hline Shoot tips anthocyanin intensity & $7.33 \mathrm{a}^{\mathrm{z}, \mathrm{y}}$ & $5.17 \mathrm{a}$ & $5.36 \mathrm{a}$ & $2.78 \mathrm{~b}$ \\
\hline Leaf blade lobing & $4.67 \mathrm{~b}$ & $4.33 \mathrm{~b}$ & $2.82 \mathrm{c}$ & $6.56 \mathrm{a}$ \\
\hline Leaf hairs & $6.67 \mathrm{ab}$ & $6.00 \mathrm{ab}$ & $5.36 \mathrm{~b}$ & $7.22 \mathrm{a}$ \\
\hline Flowering time (d) & $59.83 \mathrm{ab}$ & $58.00 \mathrm{~b}$ & $61.81 \mathrm{a}$ & $57.67 \mathrm{~b}$ \\
\hline Corolla color & $7.67 \mathrm{a}$ & $7.00 \mathrm{ab}$ & $7.00 \mathrm{ab}$ & $6.33 \mathrm{~b}$ \\
\hline Fruit length $(\mathrm{cm})$ & $10.57 \mathrm{~d}$ & $16.05 \mathrm{c}$ & $22.92 \mathrm{a}$ & $18.74 \mathrm{~b}$ \\
\hline Fruit breadth $(\mathrm{cm})$ & $10.28 \mathrm{a}$ & $8.31 \mathrm{~b}$ & $5.50 \mathrm{c}$ & $9.37 \mathrm{ab}$ \\
\hline Fruit shape & $2.67 \mathrm{c}$ & $7.00 \mathrm{~b}$ & $8.91 \mathrm{a}$ & $6.33 \mathrm{~b}$ \\
\hline Fruit weight $(\mathrm{g})$ & $226.67 \mathrm{~b}$ & $312.00 \mathrm{~b}$ & $241.55 \mathrm{~b}$ & $449.56 \mathrm{a}$ \\
\hline Fruit curvature & $1.00 \mathrm{~b}$ & $1.33 \mathrm{~b}$ & $3.18 \mathrm{a}$ & $1.00 \mathrm{~b}$ \\
\hline Fruit cross section & $4.67 \mathrm{a}$ & $1.67 \mathrm{~b}$ & $1.37 \mathrm{~b}$ & $2.33 \mathrm{~b}$ \\
\hline Fruit widest part & $5.33 \mathrm{~b}$ & $6.00 \mathrm{~b}$ & $7.00 \mathrm{a}$ & $6.78 \mathrm{a}$ \\
\hline Fruit color intensity under calyx & $1.00 \mathrm{~b}$ & $5.00 \mathrm{a}$ & $4.64 \mathrm{a}$ & $5.67 \mathrm{a}$ \\
\hline Fruit calyx color & $5.00 \mathrm{a}$ & $1.67 \mathrm{~b}$ & $0.45 \mathrm{~b}$ & $0.44 \mathrm{~b}$ \\
\hline Fruit firmness in broadest part & $7.67 \mathrm{a}$ & $5.00 \mathrm{~b}$ & $3.91 \mathrm{~b}$ & $5.67 \mathrm{~b}$ \\
\hline Fruit calyx prickles & $1.17 \mathrm{~b}$ & $1.50 \mathrm{~b}$ & $1.27 \mathrm{~b}$ & $3.89 \mathrm{a}$ \\
\hline Fruit number & $6.83 \mathrm{a}$ & $5.00 \mathrm{a}$ & $7.55 \mathrm{a}$ & $3.33 \mathrm{~b}$ \\
\hline
\end{tabular}

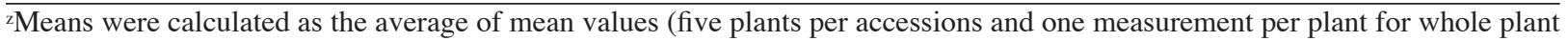
traits and five measurements per plant for the rest of vegetative, inflorescence, and fruit traits) of all accessions included in each group. 

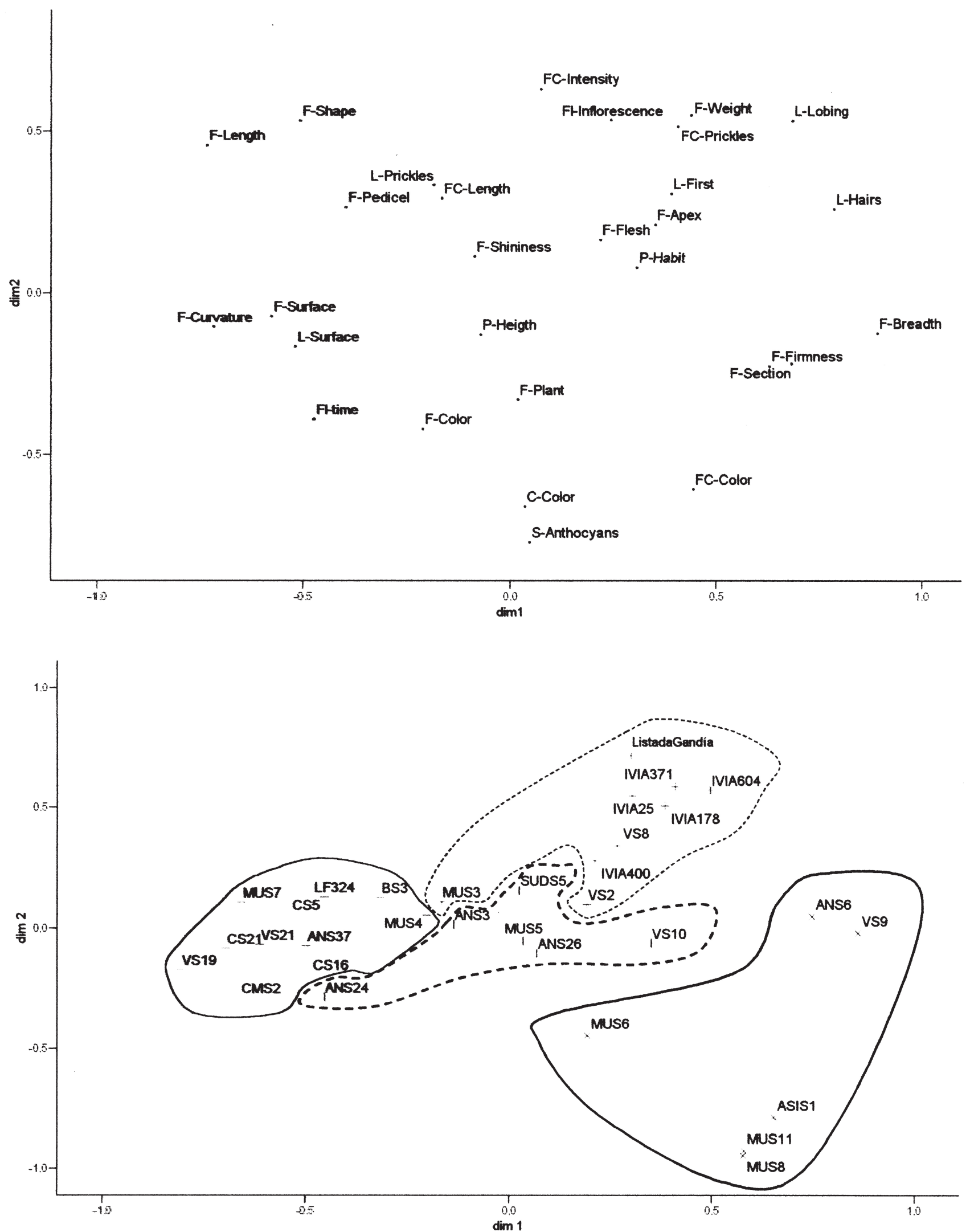

Fig. 1. Diagram showing relationships among quantitative traits used (see Table 2) for the characterization of 32 S. melongena accessions based on the two first principal components of PCA (23.0\% and $15.0 \%$ of the total variation, respectively) (above). Morphological-based similarities among the 32 S. melongena accessions based on the PCA (below). $\times=$ round type (thick continuous line) $\mid$ I = semi-long type (thick discontinuous line); ${ }_{-}=$long type (thin continuous line); $+=$ listada de Gandía type (thin discontinuous line). 


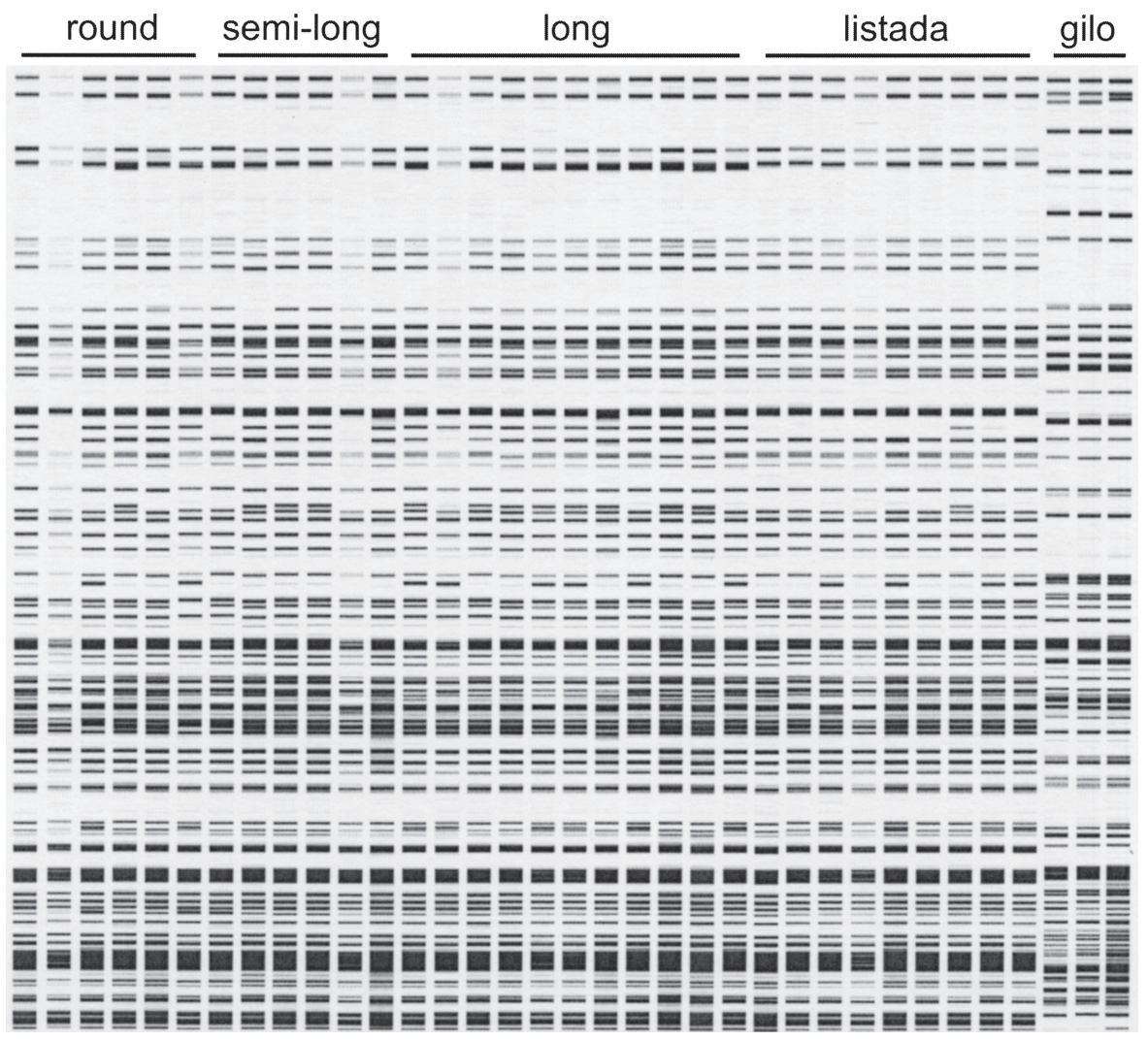

Fig. 2. Computer-generated (Genographer software) representation of a gel-like image corresponding to the fluorescent traces recorded after separation of the AFLP fragments in a capillary genetic analyser of 32 S. melongena accessions corresponding to the "round", "semi-long", "long," and "listada de Gandía" (listada) cultivar groups and to 3 S. aethiopicum (Gilo group) accessions generated by the Mse CAA-Eco ACT FAM combination.

Table 6. Gene diversity statistics (Nei, 1973) estimated from AFLP markers data for the materials studied grouped by species (S. melongena or S. aethiopicum), cultivar group ("round," "semi-long," "long," or "listada de Gandía") or region of origin within Spain (Catalonia, Valencia, Murcia, or Andalusia).

\begin{tabular}{lcccr}
\hline Groups & $\begin{array}{c}\text { No. of } \\
\text { accessions }\end{array}$ & $H^{\mathrm{z}}$ & $H_{S}^{\mathrm{z}}$ & $G_{S T}{ }^{\mathrm{T}}$ \\
\hline All accessions & $\mathbf{3 5}$ & $\mathbf{0 . 1 3 7}$ & $\mathbf{0 . 0 4 3}$ & $\mathbf{0 . 8 6}$ \\
S. melongena & 32 & 0.046 & & \\
S. aethiopicum & 3 & 0.040 & & \\
S. melongena & $\mathbf{3 2}$ & $\mathbf{0 . 0 5 6}$ & $\mathbf{0 . 0 4 2}$ & $\mathbf{0 . 3 0}$ \\
Round & 6 & 0.071 & & \\
Semi-long & 6 & 0.041 & & \\
Long & 11 & 0.030 & & \\
Listada de Gandía & 9 & 0.026 & & \\
S. melongena & & & & \\
$\quad$ (selected regions) & $\mathbf{2 6}$ & $\mathbf{0 . 0 3 7}$ & $\mathbf{0 . 0 2 8}$ & $\mathbf{0 . 2 6}$ \\
Catalonia & 3 & 0.012 & & \\
Valencia & 11 & 0.037 & & \\
Murcia & 7 & 0.034 & & \\
Andalusia & 5 & 0.039 & & \\
\end{tabular}

${ }^{\mathrm{z}} H=$ gene diversity; $H_{S}=$ average gene diversity within subpopulations; $G_{S T}=$ relative magnitude of gene differentiation among groups $\left(H_{S}\right)$ $\left.H_{T}\right)$.
When considering S. melongena, 65 (19.2\%) markers were polymorphic and allowed distinguishing morphologically similar cultivars (Fig. 2). Most of the polymorphisms $(52.3 \%)$ are the result of the presence/absence of one fragment in a single accession. No fragments were found to be present in all the accessions of one group and absent in the other groups. The same occurred when studying accessions by region of origin. For the three accessions of S. aethiopicum, there were $33(9.7 \%)$ polymorphic markers.

Despite the uneven number of accessions studied for each species ( 32 for S. melongena and three for S. aethiopicum), total diversity $\left(\mathrm{H}_{\mathrm{T}}\right)$ of the S. melongena accessions was quite similar to that of S. aethiopicum (Table 6). Genetic differentiation $\left(\mathrm{G}_{\mathrm{ST}}\right)$ among these species was very high (0.86). Regarding the cultivar groups of S. melongena, the "round" group has the greatest genetic diversity, with values $2.7,2.4$, and 1.7 times greater than those found in "listada de Gandía," "long," and "semi-long," respectively. When considering regions, diversity is much greater in Murcia, Valencia, and Andalusia than in Catalonia (Table 6). Values of genetic differentiation among groups and among regions have been moderate (Table 6).

Cluster analysis (not shown) was performed with genetic distance data groups S. aethiopicum and S. melongena in two main clusters (bootstrap of 100\%). However, within the $S$. melongena cluster it is not possible to find subclusters grouping a substantial number of accessions supported by bootstrap values of $50 \%$ or greater. In addition, the value of the coefficient of correlation between the cophenetic matrix and the genetic distances matrix is 0.77, which is low (Rohlf, 1992). Therefore, as for the morphological data, we chose to study the relationships among accessions through a PCoA.

In the PCoA with all accessions (not shown), the first coordinate explains most of the variation (70\%) and mostly accounts for the separation between S. aethiopicum and S. melongena. Therefore, we performed a PCoA using only the S. melongena accessions (Fig. 3). In this analysis, the first and second coordinates explain, respectively, $20.2 \%$ and $18.5 \%$ of the observed variation.

The PCoA scatter plot shows that each of "long," "semi-long," and "listada de Gandía" groups of accessions are plotted in a different area. On the contrary, the "round" accessions, with the exception of a subgroup constituted by three accessions that are clustered together, are spread in different areas of the plot. No regional clustering is observed, with the exception of the accessions from Catalonia, all of which are of the "long" type and are plotted together. Control cultivars used in the present study are genetically similar to the Spanish traditional cultivars (Fig. 3). The Asian cultivar ASIS1 ("round") is genetically close to two Spanish "round" cultivars; the American cultivar SUDS5 ("semi-long") is similar to a "round" cultivar; French cultivar LF324 ("long") is included in the "long" cluster; and the commercial selection 'Listada de Gandía' is genetically similar to other Spanish traditional cultivars of the "listada de Gandía" type. 


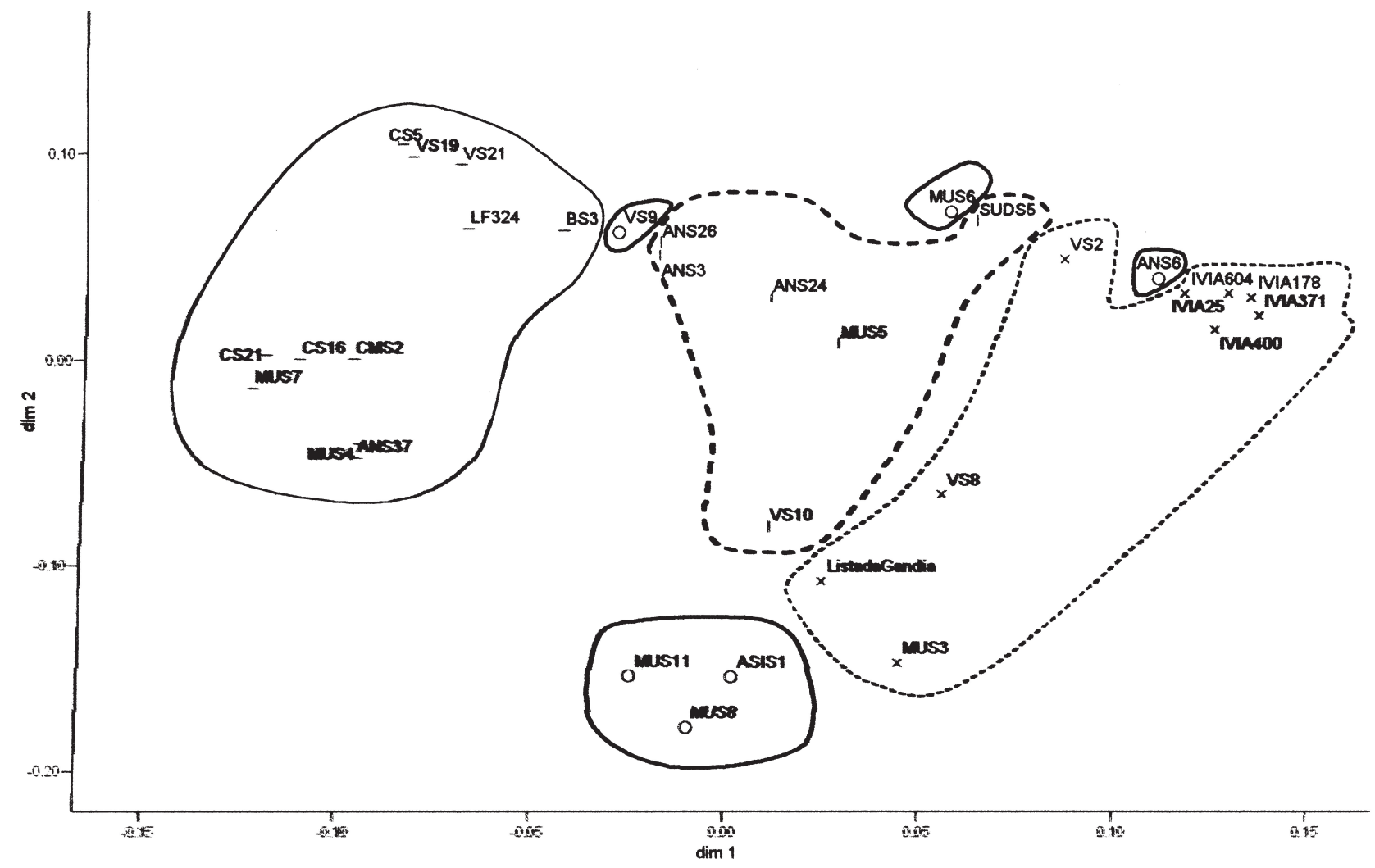

Fig. 3. Relationships between 32 eggplant cultivars based on principal coordinates analysis (first and second coordinates account for $20.2 \%$ and $18.5 \%$ of variation, respectively) using AFLP-based genetic similarities. $\times=$ round type (thick continuous line); $\mid=$ semi-long type (thick discontinuous line); $\_=$long type (thin continuous line); + = listada de Gandía type (thin discontinuous line).

Correlations between Distances. Correlation between the morphological and molecular distances of Spanish accessions of $S$. melongena is $0.68(P<0.01)$, revealing the existence of a moderate association between both measures. Correlations between the geographic distance of the collection sites and either the morphological or molecular distances are low, with values of $0.25(P<0.01)$ and $0.11(P<0.10)$, respectively.

\section{Discussion}

Spanish eggplant cultivars are neither morphologically nor molecularly differentiated from other $S$. melongena group $\mathrm{H}$ accessions from other countries, and exhibit a high degree of morphological variability, comparable to that existing in wild and weedy materials from the primary center of diversity of this crop (Karihaloo and Rai, 1995). This high diversity suggests that the Iberian Peninsula might be regarded as a secondary center of diversity for $S$. melongena group $\mathrm{H}$. Also, despite the genetic bottlenecks suffered during domestication and migration to the Iberian Peninsula, almost 20\% of the AFLP markers scored are polymorphic. The role of Spain as a bridge between Europe and North Africa, from where eggplants were introduced into western Europe, the diversity of environmental conditions, and the different uses for which eggplants have been selected in this country have contributed to the buildup of this diversity (Prohens and Nuez, 2001).

Artificial classification of cultivars of a crop species may result in groups morphologically very different one from each other because they display a characteristic syndrome for many morphological traits other than those used for the grouping; or, on the contrary, they may show a heterogeneous assortment among groups of traits other than those that allow the classification into groups (Parker, 1986; Spooner et al., 2003). The case of Spanish eggplants seems to be intermediate between these extremes. This situation can be observed in the morphological PCA plots, in which there is a clustering of accessions of the same group, although in some cases, accessions belonging to different cultivar groups show more similarities among themselves than to accessions of their respective cultivar groups.

Although, as is common in any domesticate used for its fruit (Harlan, 1992), considerable morphological variation is found in this organ, important variation has also been detected for many other traits in the eggplant collection studied. Variation in vegetative characters might be the result of an accumulation of variation on neutral traits, a consequence of selection for adaptation to specific environments, or a combination of both. In this way, high anthocyanin content may confer a greater tolerance to some stresses (Atanassova et al., 2001).

As in the case of morphological traits, there is a differentiation among cultivar groups at the molecular level, although one or more accessions of one group are more similar to accessions of other groups than to those of its own group. Additionally, some of the "round" accessions are scattered in the molecular PCoA graph. Despite the molecular similarity of the accessions of a given cultivar group, which indicates the existence of a shared genetic background, no AFLP markers are present in all accessions of a cultivar group and absent in all the other accessions, which suggests that hybridization (Sandambam, 1964) and in- 
trogression among the different groups may have been common events in the evolution of this crop. In fact, the low bootstrap values for the nodes of the tree generated with the AFLP data indicates that evolution of Spanish cultivars of eggplant, rather than a tree-model, has followed a network-model, as it is common for the genealogical relationships within a species (Crandall and Templeton, 1996). This hypothesis would be supported by the moderate values of genetic differentiation among cultivar groups. The fact that the traits for which the different exclusive cultivar groups are distinguished, like fruit shape and color, are under the control of a few genes or QTLs (Doganlar et al., 2002; Frary et al., 2003; Kalloo, 1993) indicates that hybridization among individuals belonging to different groups could lead, after fixation in the subsequent generations, to new lines with traits corresponding to different agronomic groups that would share, as an average and under no selection, $50 \%$ of the genes for which the parents differ. This could explain the existence of accessions that are molecularly similar but belong to different agronomic groups. Because of these arguments we consider that it would be difficult to find individual AFLP markers that are able to distinguish the four cultivar groups.

The historical records (Nuez et al., 2002; Prohens and Nuez, 2001; Watson, 1998) indicate that the eggplants introduced by the Arabs, at least in the earlier times, were not of the "long" type. As far as we know, al-Andalus agronomists and other European authors of the Middle Ages do not depict or make reference to this type of eggplant. Therefore, it seems that the "long" types were introduced later than "round" and "semi-long" types. Alternatively, these cultivars might have arisen recently and independently of other "long" cultivars from other places, a process that might have taken place by loss of existing gene function or regulation (Lester and Daunay, 2003). Any of these processes could explain its lower genetic diversity when compared to the "long" and "semi-long" types. In the same way, the lower diversity of the "listada de Gandía" group may reflect a common origin, a restricted geographical distribution, or both.

The low level of correlation between the geographic and the morphological or molecular distances probably is a consequence of the frequent movements and exchanges of seeds between farmers. Nonetheless, the 'listada de Gandía' type is widespread only in the coastal area of Valencia and Murcia, and seems to have a good adaptation to these specific conditions. For the other groups, there are representatives in each of the main regions studied, except for Catalonia, where all the cultivars studied are of the "long" type. Nuez et al. (2002) and Prohens and Nuez (2001) already described that in Catalonia most of the cultivars are "long," which is probably linked to a specific use of the eggplant in the gastronomy of the area (longitudinally cut, stuffed halves of eggplant) for which cultivars of this type are especially suited.

The positive correlation between the morphological and molecular diversity is useful in eggplant germplasm management and breeding. In this way, the establishment of nuclear collections based on morphological data will probably encompass an important part of the molecular diversity, and vice versa. Also, the fact that most of the morphological and molecular diversity can be found in accessions from a single region can reduce the costs of germplasm collection and conservation (Hawkes et al., 2000). In this way, almost all of the genetic diversity of Spanish eggplants is represented in each of the Andalusia, Murcia, or Valencia regions. The greater genetic diversity found in the "round" cultivar group indicates that these cultivars should be more represented than others in the screening for sources of varia- tion for traits for which there is no previous information on the distribution of diversity among groups. In addition, the degree of polymorphism detected with AFLP markers suggests that they may be adequate to detect duplicates or accessions genetically very similar in the collections.

Regarding eggplant breeding, the correlation between morphological and molecular traits indicates that selection of morphologically different individuals may lead to the identification of genetically distant individuals and vice versa. As in other Solanaceae (Paz and Veilleux, 1997; Rodríguez-Burruezo et al., 2003), choosing genetically distant parents may be helpful for obtaining hybrids heterotic for yield. In fact, heterosis after crossing unrelated individuals has already been described in eggplant (Kalloo, 1993; Sandambam, 1962). Also, AFLP markers, because of their levels of polymorphism in eggplant, could be used to obtain fingerprints of cultivars, even when they are morphologically similar. Therefore, these markers can be used for the protection of cultivars and for detecting "essentially derived" cultivars.

In conclusion, this work shows that Spanish cultivars of eggplant display a considerable diversity, that the evolution of the crop probably has involved frequent hybridizations and introgressions among cultivar groups, and that there is no clear regional differentiation at a morphological or molecular level. All this information is useful for the conservation of germplasm and for the genetic improvement of this crop.

\section{Literature Cited}

Abu-Zacaría. 1802. Agriculture book (in Spanish). Imprenta Real, Madrid, Spain.

Atanassova, B., S. Daskalov, L. Shtereva, and E. Balatcheva. 2001. Anthocyanin mutations improving tomato and pepper tolerance to adverse climatic conditions. Euphytica 120:357-365.

Benham, J. 2001. Genographer 1.6. 15 May 2003. <http://hordeum.oscs. montana.edu/genographer/>.

Buntjer, J.B. 2001. Phylogenetic computer tools. Vers. 1.3. Wageningen Univ., Wageningen, The Netherlands.

Crandall, K.A. and A.R. Templeton. 1996. Applications of intraspecific phylogenetics: Problems and solutions, p. 81-99. In: P.H. Harvey, A.J.L. Brown, and J.M. Smith (eds.). New uses for new phylogenies. Oxford Univ. Press, Oxford, U.K.

Daunay, M.C. 1996. Eggplant through ages and uses (in French). PHM Revue Horticole 374:35-36.

Doganlar, S., A. Frary, M.C. Daunay, R.N. Lester, and S.D. Tanksley. 2002. Conservation of gene function in the Solanaceae as revealed by comparative mapping of domestication traits in eggplant. Genetics 161:1713-1726.

Felsenstein, J. 1993. PHYLIP (Phylogeny Inference Package). Vers. 3.5c. Dept. of Genetics, Univ. of Washington, Seattle.

Frary, A., S. Doganlar, M.C. Daunay, and S.D. Tanksley. 2003. QTL analysis of morphological traits in eggplant and implications for conservation of gene function during evolution of solanaceous species. Theor. Appl. Genet. 107:359-370.

Furini, A. and J Wunder. 2004. Analysis of eggplant (Solanum melongena)-related germplasm: Morphological and AFLP data contribute to phylogenetic interpretations and germplasm utilization. Theor. Appl. Genet. 108:197-208.

Harlan, J.R. 1992. Crops and man. 2nd ed. Amer. Soc. Agron., Madison, Wis.

Hawkes, J.G., N. Maxted, and B.V. Ford-Lloyd. 2000. The ex situ conservation of plant genetic resources. Kluwer Academic Publ., Dordrecht, The Netherlands.

International Board for Plant Genetic Resources. 1990. Descriptors for eggplant. Intl. Board Plant Genet. Resources, Rome.

Isshiki, S., H. Okubo, and K. Fujieda. 1994. Phylogeny of eggplant 
and related Solanum species constructed by allozyme variation. Sci. Hort. 59:171-176.

Isshiki, S., S. Suzuki, and K. Yamashita. 2003. RFLP analysis of mitochondrial DNA in eggplant and related Solanum species. Genet. Resources Crop Evolution. 50:133-137.

Isshiki, S., T. Uchiyama, Y. Tashiro, and S. Miyazaki. 1998. RFLP analysis of a PCR amplified region of chloroplast DNA in eggplant and related Solanum species. Euphytica 102:295-299.

Jenkins, J.A. 1948. The origin of the cultivated tomato. Econ. Bot. 2:379-392.

Jones, C. J., K.J. Edwards, S. Castaglione, W.O. Winfield, F. Sala, C. van de Wiel, G. Bredemeijer, B. Vosman, M. Matthes, A. Daly, R. Brettschenider, P. Bettini, M. Buiatti, B. Maestri, A. Malcevschi, N. Marmiroli, R. Aert, G. Volckaert, J. Rueda, R. Linacero, A. Vázquez, and A. Karp. 1997 Reproducibility testing of RAPD, AFLP and SSR markers in plants by a network of European laboratories. Mol. Breeding 3:381-390.

Kalloo, G. 1993. Eggplant, Solanum melongena L., p. 587-604. In: G. Kalloo and B.O. Bergh (eds.). Genetic improvement of vegetable crops. Pergamon Press, Oxford, U.K.

Karihaloo, J.L. and L.D. Gottlieb. 1995. Allozyme variation in the eggplant, Solanum melongena L. (Solanaceae). Theor. Appl. Genet. 90:578-583.

Karihaloo, J.L. and M. Rai. 1995. Significance of morphological variability in Solanum insanum L. (sensu lato). Plant Genet. Resources Nwsl. 103:24-26.

Karihaloo, J.L., M. Kaur, and S. Singh. 2002. Seed protein diversity in Solanum melongena L. and its wild and weedy relatives. Genet. Resources Crop Evol. 49:533-539.

Karihaloo, J.L., S. Brauner, and L.D. Gottlieb. 1995. Random amplified polymorphic DNA variation in the eggplant, Solanum melongena $\mathrm{L}$. (Solanaceae). Theor. Appl. Genet. 90:767-770.

Lester, R.N. and M.C. Daunay. 2003. Diversity of African vegetable Solanum species and its implications for a better understanding of plant domestication, p. 137-152. In: H. Knüpffer and J. Ochsmann (eds.). Rudolf Mansfeld and plant genetic resources. Schriften zu Genetischen Resourcen 22, Institut für pflanzengenetic und Kulturpflanzenforschung, Gatersleben, Germany.

Lester, R.N. and S.M.Z. Hasan. 1991. Origin and domestication of the brinjal eggplant, Solanum melongena, from S. incanum, in Africa and Asia, p. 369-387. In: J.G. Hawkes, R.N. Lester, M. Nee, and N. Estrada (eds.). Solanaceae III: Taxonomy, chemistry, evolution. Linnean Soc. of London, London.

Lester, R.N., J.J.H. Hakiza, N. Stavropoulos, and M.M. Teixeira. 1986. Variation patterns in the african scarlet eggplant, Solanum aethiopicum L., p. 283-307. In: B.T. Styles (ed.). Infraspecific classification of wild and cultivated plants. Clarendon Press, Oxford, U.K.

Mace, E.S., R.N. Lester, and C.G. Gebhardt. 1999. AFLP analysis of genetic relationships among the cultivated eggplant, Solanum melongena L., and wild relatives (Solanaceae). Theor. Appl. Genet. 99:626-633.

Mantel, N.A. 1967. The detection of disease clustering and a generalised regression approach. Cancer Res. 27:209-220.

Mohammadi, S.A. and B.M. Prasanna. 2003. Analysis of genetic diversity in crop plants - Salient statistical tools and considerations. Crop Sci. 43:1235-1248

Navarro, D. 1880. Perfecciones cultivation of vegetales (in Spanish). Vol. II. Establecimiento Tipográfico de Pedro Núñez, Madrid.

Nei, M. 1973. Analysis of gene diversity in subdivided populations. Proc. Natl. Acad. Sci. USA 70:3321-3323.
Nuez, F., J. Prohens, J.V. Valcárcel, and P. Fernández de Córdova. 2002. Collection of eggplant seeds from the Centro de Conservación y Mejora de la Agrodiversidad Valenciana (in Spanish). Ministerio de Ciencia y Tecnología, Madrid.

Nunome, T., K. Ishiguro, T. Yoshida, and M. Hirai. 2001. Mapping of fruit shape and color development traits in eggplant (Solanum melongena L.) based on RAPD and AFLP markers. Breeding Sci. 51:19-26.

Nunome, T., K. Suwabe, A. Ohyama, and H. Fukuoka. 2003. Characterization of trinucleotide microsatellites in eggplant. Breeding Sci. 53:77-83.

Parker, P.F. 1986. The classification of cultivated plants - Problems and prospects, p. 99-114. In: B.T. Styles (ed.). Infraspecific classification of wild and cultivated plants. Clarendon Press, Oxford, U.K.

Paz, M.M. and R.E. Veilleux. 1997. Genetic diversity based on randomly amplified polymorphic DNA (RAPD) and its relationship with the performance of diploid potato hybrids. J. Amer. Soc. Hort. Sci. 122:740-747.

Pearce, K. and R.N. Lester. 1979. Chemotaxonomy of the cultivated eggplant-A new look at the taxonomic relationships of Solanum melongena L., p. 615-628. In: J.G. Hawkes, R.N. Lester, and A.D. Skelding (eds.). The biology and taxonomy of the Solanaceae. Linnean Soc. of London, London.

Prohens, J. and F. Nuez. 2001. Spanish tradicional varieties of eggplant (in Spanish). Vida Rural 130:46-50.

Prohens, J., J.V. Valcárcel, E. Solbes, and F. Nuez. 2003. Characterization and typification of Spanish eggplant landraces. Capsicum Eggplant Nwsl. 22:135-138.

Rodríguez-Burruezo, A., J. Prohens, and F. Nuez. 2003. Performance of hybrid segregating populations of pepino (Solanum muricatum) and its relation to genetic distance among parents. J. Hort. Sci. Biotechnol. 78:911-918.

Rohlf, F.J. 1992. NTSYS-pc (numerical taxonomy and multivariate analysis system). Vers. 1.70. Exeter, Setauket, N.Y.

Sakata, Y. and R.N. Lester. 1994. Chloroplast DNA diversity in eggplant (Solanum melongena) and its related species S. incanum and S. marginatum. Euphytica 80:1-4.

Sakata, Y. and R.N. Lester. 1997. Chloroplast DNA diversity in brinjal eggplant (Solanum melongena L.) and related species. Euphytica 97:295-301.

Sakata, Y., T. Nishio, and P.J. Matthews. 1991. Chloroplast DNA analysis of eggplant (Solanum melongena) and related species for their taxonomic affinity. Euphytica 55:21-26.

Sandambam, C.N. 1962. Heterosis in eggplant (Solanum melongena Linn.)-Prospects and problems in commercial production of hybrid seeds. Econ. Bot. 16:71-76.

Sandambam, C.N. 1964. Natural cross-pollination in eggplant. Econ. Bot. 18:128-131.

Spillane, C. and P. Gepts. 2001. Evolutionary and genetic perspectives on the dynamics of crop genepools, p. 25-70. In: H.D. Cooper, C. Spillane, and T. Hodgkin (eds.). Broadening the genetic base of crop production. Intl. Plant Genet. Resources Inst. and Food and Agr. Org., Rome.

Spooner, D.M., W.L.A. Hetterscheid, R.G. van den Berg, and W.A. Brandenburg. 2003. Plant nomenclature and taxonomy-An horticultural and agronomic perspective. Hort. Rev. 28:1-60.

Watson, A.M. 1998. Agricultural innovations in the first times of the Islamic world (in Spanish). Editorial de la Universidad de Granada, Granada, Spain.

Yeh, F.C. and T.J.B. Boyle. 1997. Population genetic analysis of codominant and dominant markers and quantitative traits. Belgian J. Bot. 129:157. 